\title{
Strategi Bersaing Keripik Singkong Cap Gerus Produksi UKM Sumekar Pratiwi Kabupaten Tuban
}

\author{
Mohd. Harisudin, Setyowati, Nizar Utami \\ Program Studi Agribisnis Fakultas Pertanian Universitas Sebelas Maret, \\ Email: mohamad_h@staff.uns.ac.id
}

\begin{abstract}
Abstrak
Penelitian ini bertujuan untuk mengkaji faktor-faktor penentu keberhasilan keripik singkong cap Gerus, mengkaji posisi bersaing keripik singkong cap Gerus, serta merumuskan alternatif strategi bersaing yang dapat diterapkan UKM Sumekar Pratiwi dalam pemasaran keripik singkong cap Gerus. Penelitian ini menggunakan metode dasar deskripsi analisis. Penentuan subyek penelitian dilakukan secara purposive (sengaja). Data yang digunakan adalah data primer dan data sekunder. Metode analisis data menggunakan Competitive Profile Matrix (CPM). Hasil penelitian menunjukkan faktor-faktor penentu keberhasilan keripik singkong cap gerus. Hasil analisis CPM keripik singkong cap Gerus $(3,116)$ menempati posisi kedua dibandingkan dengan pesaingnya yaitu keripik singkong $C(2,058)$ dan keripik singkong $D(1,655)$. Keripik singkong $B(3,171)$ berada pada posisi pertama. Alternatif strategi bersaing yang dapat diterapkan untuk keripik singkong cap Gerus adalah mempromosikan brand Gerus melalui kegiatan sales-force promotion, melakukan positioning produk dengan menciptakan citra produk berkualitas yaitu rasa yang lebih gurih, memiliki merek yang paling dikenal, desain label yang lebih menarik, serta informasi label yang lebih informatif, dan melakukan benchmark warna produk dan rasa akhir setelah makan serta menetapkan harga diskon kuantitas kepada konsumen akhir.
\end{abstract}

Kata kunci: competitive profile matrix, keripik singkong, strategi bersaing

\section{PENDAHULUAN}

Sektor pertanian merupakan sektor yang berperan penting dalam menghasilkan bahan pangan untuk mencukupi kebutuhan primer bagi setiap individu. Hasil pertanian yang melimpah bertujuan sebagai penggerak pembangunan pertanian dengan didorong keberadaan industri yang berperan dalam mengubah produk pertanian menjadi variasi produk yang berguna sesuai dengan selera dan kebutuhan konsumen.

Singkong sebagai salah satu sumber karbohidrat dapat diolah menjadi berbagai macam bentuk olahan makanan dan bernilai ekonomis. Prospek pasar ini tentunya sebagai peluang usaha yang sangat baik bagi pengembangan industri kecil berskala rumah tangga (Rukmana, 2011). Keripik singkong merupakan produk olahan singkong yang banyak di produksi di Kabupaten Tuban, salah satunya melalui usaha kecil menengah. Melihat pangsa pasar yang cukup besar yang didukung ketersediaan bahan baku singkong, maka UKM Sumekar Pratiwi mengambil bagian dalam pasar komoditi olahan singkong.

UKM Sumekar Pratiwi merupakan pelaku usaha kecil menengah yang mengolah dan memasarkan keripik singkong di Kabupaten Tuban. Keripik singkong cap Gerus yang menjadi produk unggulan dari UKM Sumekar Pratiwi menggunakanbahan baku (singkong) lokal Kabupaten Tuban. Perkembangan usaha UKM Sumekar Pratiwi menarik para pelaku usaha kecil menengah yang lain untuk berkompetisi dalam merebut pangsa pasar untuk memenuhi permintaan keripik singkong. Seiring dengan meningkatnya pendapatan masyarakat serta adanya daya tarik permintaan produk keripik singkong di pasar, maka bermunculanlah produk sejenis di pasar. Hal tersebut meyebabkan munculnya merek-merek 
Agrisaintifika

Jurnal Ilmu-Ilmu Pertanian

Vol. 1, No. 1, 2017

baru terkait produk yang sejenis, diantaranya adalah UKM Dian Pangestu, UKM Yugus, dan UKM AI-Wira, UKM Wahyu Barokah, UKM Dua Putra, UKM Ana, UKM Prima Rasa, UKM Sarana Rezeki. Variasi produk keripik singkong yang ada di Kabupaten Tuban saat ini dapat dilihat pada Tabel 1.

Dalam perjalanan usahanya, usaha keripik singkong cap Gerus dihadapkan pada persaingan usaha yang semakin ketat seperti munculnya produk sejenis dengan bahan baku yang sama yang tercantum pada Tabel 1 . Adanya jenis produk, konsep usaha dan target konsumen yang sama menyulitkan UKM Sumekar Pratiwi dalam memposisikan produknya.

Promosi dan persaingan produk melalui media cetak dan event tidak cukup memberi pengaruh pada perkembangan usaha jika hal serupa juga dilakukan para pesaing usaha (competitor). Kreativitas dan inovasi yang berkelanjutan diperlukan supaya produk keripik singkong yang diproduksi UKM Sumekar Pratiwi dapat terus berkembang.

Menanggapi hal tersebut, didorong keinginan mencegah pasar cepat jenuh, serta keinginan untuk mendapatkan pangsa pasar yang tetap dan membesar, maka faktor penting yang harus diperhatikan adalah pemahaman UKM Sumekar Pratiwi dalam memahami keinginan konsumen terkait atribut yang dipertimbangkan dalam melakukan pembelian keripik singkong.

Untuk mengetahui apakah konsumen menyukai atau tidak, atau mengetahui apa yang dikeluhkan konsumen, maka dapat dilakukan survey konsumen dengan cara sederhana yaitu menanyakan pendapat konsumen terhadap produk keripik singkong yang dihasilkan dengan cara menanyakan kekurangannya sebagai bahan perbaikan melalui atribut-atribut yang dipertimbangkan (Jaya et al., 2012).

Suatu perusahaan dalam menjalankan strategi yang kompetitif diharapkan secara terus menerus mengetahui dan memantau pergerakan pesaingnya. Menurut Rangkuti
(1997), perusahaan harus melihat secara objektif kondisi internal dan kondisi eksternal sehingga perusahaan dapat mengantisipasi perubahan lingkungan eksternal yang sangat penting untuk memperoleh keunggulan bersaing dan memiliki produk yang sesuai keinginan konsumen dengan dukungan yang optimal dari sumberdaya yang ada. Porter (1998), menyatakan bahwa keunggulan bersaing adalah suatu posisi dimana sebuah perusahaan menguasai sebuah ajang persaingan bisnis.

Sudah beberapa tahun ini, UKM Sumekar Pratiwi dalam menjalankan usahanya mengalami persaingan yang semakin ketat dengan munculnya produk sejenis, terutama usaha berskala kecil dan menengah yang mempunyai konsep usaha yang sama, target konsumen yang sama, serta lokasi geografis para pesaing yang tidak begitu jauh. Adanya persaingan tersebut mengakibatkan pendapatan yang diperoleh dari penjualan keripik singkong cap Gerus berfluktuatif. Hal tersebut mempengaruhi kinerja perusahaan dan tidak jarang perusahaan mengalami kesulitan untuk membayar gaji karyawannya. Data penjualan produk keripik singkong produksi UKM sumekar Pratiwi pada tahun 2016 disajikan pada Tabel 2.

Mendasarkan data pada Tabel 2, maka UKM Sumekar Pratiwi dalam memasarkan produk keripik singkong cap Gerus harus mengetahui dengan pasti kelebihan dan kelemahan yang dimiliki produknya. Memahami kinerja atribut produk merupakan hal penting dalam menentukan keberhasilan pemasaran suatu perusahaan. Atribut produk yang perlu diketahui dari pesaing dan yang harus dipantau oleh UKM Sumekar Pratiwi adalah dengan membandingkan atribut produk keripik singkong cap Gerus dengan produk pesaing yaitu: rasa, volume (gram), warna produk, kerenyahan produk, daya tahan produk, rasa akhir setelah makan, merek, harga, desain kemasan, kualitas kemasan, desain label, dan kelengkapan label. Hal tersebut penting dilakukan untuk mengetahui posisi bersaing dan perumusan alternatif strategi bersaing dalam menghadapi 
banyaknya pesaing yang ada dipasar dan mencapai tujuan bisnis.

Penelitian ini bertujuan untuk mengkaji faktor-faktor penentu keberhasilan keripik singkong cap Gerus, mengkaji posisi bersaing keripik singkong cap Gerus, serta merumuskan alternatif strategi bersaing yang dapat diterapkan UKM Sumekar Pratiwi dalam pemasaran keripik singkong cap Gerus di pasar.

\section{METODE PENELITIAN}

Metode dasar yang digunakan dalampenelitian ini adalah deskripsi analitis. Teknik pelaksanaan penelitian dengan pendekatan studi kasus yaitu memusatkan diri secara intensif pada suatu obyek tertentu. Data studi kasus dapat diperoleh dari semua pihak yang bersangkutan atau dikumpulkan dari berbagai sumber (Nawawi, 2003). Metode penentuan subyek penelitian dilakukan secara purposive (sengaja), yaitu UKM Sumekar Pratiwi yang sedang menghadapi permasalahan pemasaran dan ingin meningkatkan penjualan keripik singkong cap Gerus dengan menerapkan alternatif strategi bersaing terhadap pesaing dari produk sejenis di pasar.

Key informant sebagai sumber data dalam penelitian ini berdasarkan pada asas subyek yang menguasai permasalahan dan bersedia memberikan informasi lengkap dan akurat yaitu pemilik UKM Sumekar Pratiwi, staf pemasar karena berada di lapang dan menghadapi konsumen langsung sehingga mengerti apa yang diinginkan oleh konsumen, produsen keripik singkong (pesaing) karena berdasarkan kapasitas produksi dan pemasaran keripik singkong lebih unggul dari keripik singkong cap Gerus sehingga penguasaan pasar luas, serta konsumen akhir dipilih karena sering melakukan pembelian ulang terhadap produk yaitu lebih dari 10 kali. Pengambilan panelis sebagai penilai kinerja atribut dilakukan secara purposive (sengaja) yaitu panelis (tidak terlatih) yang bersedia merasakan dan menilai berbagai faktor-faktor penentu keberhasilan dari keripik singkong yang bertujuan untuk mengetahui gambaran kinerja keripik singkong cap Gerus dan produk pesaing. Panelis tidak terlatih berjumlah 30 orang (Soekarto, 1981) yang menetap di Kabupaten Tuban. Syarat seorang panelis adalah berumur 20-55 tahun dengan keadaan sehat (jasmani dan rohani) mampu merasakan dan memberikan penilain terhadap produk serta sering membeli keripik singkong yaitu minimal pernah melakukan 3 kali pembelian. Metode analisis untuk merumuskan strategi bersaing bagi UKM menurut Harisudin (2011) adalah Competitive Profile Matrix (CPM). Tahapan pengolahan dan analisis data untuk CPM adalah:

\section{Faktor-faktor Penentu Keberhasilan}

Faktor penentu keberhasilan keripik singkong ditentukan melalui key informant melalui teknik indepth interview, sehingga untuk validasinya dibutuhkan bantuan alat analisis triangulasi sumber. Menurut Sutopo (2002), triangulasi sumber adalah sebuah teknik dalam memeriksa keabsahan data yang didasari pola fikir fenomenologi yang bersifat multiperspektif. Artinya untuk menarik simpulan diperlukan tidak hanya satu cara pandang. Cara pandang tersebut akan dapat dipertimbangkan beragam fenomena yang muncul dan selanjutnya dapat ditarik simpulan yang lebih mantap dan lebih bisa diterima kebenaranya.

\section{Posisi Bersaing}

CPM digunakan untuk mengetahui posisi relatif Keripik Singkong Cap Gerus produksi UKM Sumekar Pratiwi dibandingkan dengan 3 pesaing utamanya. Penilaian CPM diukur berdasarkan faktor-faktor penentu keberhasilan keripik singkong yang dianalisis yaitu rasa, volume (gram), warna produk, kerenyahan, daya tahan, rasa akhir setelah makan, merek, harga, desain kemasan, kualitas kemasan, desain label, dan kelengkapan label. Penentuan bobot oleh key informant dengan metode paired comparasion (Kinnear and Taylor, 1991). Penentuan bobot pada setiap variabel digunakan skala 1 sampai 5 yaitu: 
Agrisaintifika

Jurnal Ilmu-Ilmu Pertanian

Vol. 1, No. 1, 2017

Harisudin, et al. 2017

1 = jika indikator horizontal sangat kurang penting daripada indikator vertikal.

2 = jika indikator horizontal kurang penting daripada indikator vertikal.

3 = jika indikator horizontal sama penting dengan indikator vertikal.

$4=$ jika indikator horizontal lebih penting daripada indikator vertikal.

$5=$ jika indikator horizontal sangat lebih penting dari indikator vertikal.

Rumus:

$$
a_{i}=\frac{x_{i}}{\sum_{\mathrm{i}=1}^{\mathrm{n}} x_{i}}
$$

$$
\begin{aligned}
\text { Keterangan: } \alpha_{i} & =\text { Bobot Variabel ke-i } \\
& x_{i}=\text { Nilai Variabel ke- } i \\
i & =1,2,3, \ldots n \\
n & =\text { jumlah variable }
\end{aligned}
$$

Pemberian nilai rating untuk produk yang dianalisis tergantung pada kondisi relatif produkpesaing dan dinilai oleh panelis. Penentuan dan penilaian peringkat mengacu kepada kekuatan dan kelemahan angka 1 sampai 4, yaitu:

$1=$ jika produk kondisinya sangat lemah dibandingkan pesaing.

$2=$ jika produk kondisinya lemah dibandingkan pesaing.

$3=$ jika produk kondisinya kuat dibandingkan pesaing.

$4=$ jika produkkondisinya sangat kuat dibandingkan pesaing.

Penilaian peringkat dari ke-30 panelis untuk masing-masing produk dikalikan dengan nilai bobot dari masing-masing faktor penentu keberhasilan untuk setiap produk yang dibandingkan. Dari serangkaian proses kerja diatas, kemudian disusunlah sebuah tabel struktur penilaian CPM untuk menilai kinerja keripik singkong Cap Gerus produksi UKM Sumekar Pratiwi sebagaimana yang tertulis pada Tabel 4.

Keuntungan dari CPM yaitu dapat langsung membandingkan produk dengan pesaingnya, dapat menciptakan citra perusahaan yang kuat karena perusahaan mampu menyampaikan informasi mengenai keunggulan kompetitifnya (Harisudin, 2011; David, 2011). Selain itu, CPM akan mendorong perusahaan untuk lebih responsif terhadap segala sesuatu yang terjadi di perusahaan, memberikan inovasi kepada perusahaan supaya lebih inovatif, efisien, dan kompetitif dibandingkan dengan pesaing (Capps dan Glissmeyer, 2012).

\section{Alternatif Strategi Bersaing}

Strategi bersaing dirumuskan dengan melihat pada hasil CPM (Competitive Profile Matrix) produk dengan total skor tertinggi sebagai pemimpin pasarmenurut penialian konsumen. Penilaian perbandingan (Benchmarking) adalah alat manajemen yang telah banyak digunakan untuk mengidentifikasi dan meningkatkan kemampuan pemasaran yang berharga melalui cara perbandingan (Vorhies \& Morgan, 2005). Porter (1998), menyatakan bahwa inti dari perumusan strategi bersaing adalah menghubungkan produk dengan lingkungannya yang mencakup kekuatan-kekuatan sosial dan juga kekuatan-kekuatan ekonomi. Keunggulan bersaing diterapkan bagi suatu produk untuk meraih keuntungan ekonomi diatas laba yang mampu diraih pesaing di pasar dalam industri yang sama. Fahy (2002) dan David (2011), menambahkan bahwa keunggulan bersaing yang berkelanjutan (Sustainable Competitive Advantage-SCA) adalah keunggulan yang tidak mudah ditiru, membuat suatu produk dapat merebut dan mempertahankan posisinya sebagai pimpinan pasar. Karena sifatnya yang tidak mudah ditiru, keunggulan bersaing yang berkelanjutan merupakan satu strategi bersaing yang dapat mendukung kesuksesan suatu perusahaan untuk jangka waktu yang lama. CPM dapat menjadi salah satu jalan untuk mencapai dan menjaga keunggulan bersaing yang berkelanjutan sebuah produk (Harisudin, 2011). Matthews (2005), menyatakan bahwa keunggulan bersaing produk/organisasi dapat dicapai melalui relational architecture, reputation, innovation, dan strategic assets. 
Agrisaintifika

Jurnal Ilmu-Ilmu Pertanian

Vol. 1, No. 1, 2017

Harisudin, et al. 2017

\section{HASIL DAN PEMBAHASAN}

Faktor-faktor Penentu Keberhasilan Keripik Singkong Cap Gerus

Faktor penentu keberhasilan dari keripik singkong yang berhasil diidentifikasi adalah: rasa, volume (gram), warna produk, kerenyahan, daya tahan, rasa akhir setelah makan, merek, harga, desain kemasan, kualitas kemasan, desain label, dan kelengkapan label. Mengacu pada hasil identifikasi yang menjadi penentu keberhasilan dari keripik singkong menghasilkan karakteristik keripik singkong cap Gerus yang dinilai oleh panelis yaitu: Sebanyak 22 panelis $(80 \%)$ menyatakan bahwa rasa gurih yang pas, rasa gurih dihasilkan terkait dengan penggunaan bahan baku alami serta pengulangan minyak goreng yang digunakan dalam penggorengan selanjutnya sesuai dengan standar yang telah ditetapkan. Sebanyak 14 panelis (46,6\%) menyatakan bahwa volume (gram) yang ditawarkan beragam yaitu 160 gram, 250 gram dan 500 gram dikemas dalam plastik PP (Polypropylene) ketebalan $1 \mathrm{~mm}$. Sebanyak 23 panelis $(76,66 \%)$ menyatakan keripik singkong cap Gerus berwarna cukup cerah dan cukup menarik (tidak gelap), namun perlu dilakukan pengecekan dalam setiap proses pembuatan dan bahan-bahan yang digunakan.

Sebanyak 12 panelis (40\%) menilai bahwa keripik singkong cap Gerus mempunyai tingkat kerenyahan yang baik, hal tersebut dikarenakan sebelum penggorengan dilakukan perlakuan perendaman singkong dalam larutan asam asetat selama 2-4 jam dan dikemas dalam bahan pengemas kualitas $1 \mathrm{~mm}$. Sebanyak 18 panelis $(59,99 \%)$ menilai bahwa keripik singkong cap Gerus mampu tahan simpan lama yaitu 4-6 bulan disebabkan karena UKM Sumekar pratiwi selalu menjaga kualitas bahan baku, alat, tempat produksi meskipun proses produksi yang dilakukan secara sederhana dengan teknologi manual serta informasi daya tahan produk sudah tercantum pada label kemasan (kode expired) lengkap. Sebanyak 12 panelis $(73,33 \%)$ menilai bahwa setelah mengonsumsi keripik singkong cap Gerus tidak terdapat efek apapun, akan tetapi sebanyak 18 panelis mengatakan bahwa terdapat sedikit efek pahit setelah mengonsumsi keripik singkong tersebut. Sebanyak 22 panelis $(73,33 \%)$ menyatakan bahwa merek cap Gerus sudah dikenal dan diketahui dari teman, hal tersebut disebabkan keripik singkong cap Gerus sering diikutkan pada kegiatan pameran atau event tertentu yang sekaligus dipergunakan sebagai media promosi, serta promosi melalui mulut ke mulut ditetapkan langsung melalui konsumen tetap.

Sebanyak 17 panelis $(56,66 \%)$ menilai bahwa harga keripik singkong cap Gerus yang ditawarkan sesuai dengan volume (gram) yaitu Rp.6.000 (160 gram), Rp.8.000 (250 gram) dan Rp.15.000 (500 gram) dan masih bisa dijangkau oleh target konsumen. Sebanyak 15 panelis $(50 \%)$ menilai bahwa tampilan pembuka kemasan menarik karena kemasan produk dipressing dengan alat press khusus sehingga tampilan kemasan terlihat rapi serta mempunyai kemudahan dalam membuka kemasan. Panelis sejumlah 21 (69,99\%) menilai bahan kemasan terkesan kaku dan tebal sehingga keripik singkong didalam kemasan terkesan menarik, dalam hal ini produk dikemas dalam plastik PP (Polypropylene) yang berguna untuk mempertahankan kualitas produk supaya aman, steril, dan tetap terjaga kerenyahannya. Sebanyak 22 pnelis (73,32\%) menyatakan bahwa pemilihan tulisan, pemilihan huruf, warna huruf, dan ukuran huruf sangat jelas dan ukuran besar icon gambar keripik singkong sesuai dengan ukuran kemasan, sehingga tata letak desain label yang dihasilkan sangat sesuai, serta desain label produk Gerus yang selalu diperbarui menjadi daya tarik bagi konsumen.

Sebanyak 25 panelis $(83,32 \%)$ menilai bahwa label pada keripik singkong cap Gerus sudah lengkap yaitu nama, komposisi, berat bersih, alamat pihak yang memproduksi, kode expired (tanggal, bulan, tahun), label, halal MUI, BPOM, P-IRT (izin Dinkes) dan kode produksi. Keterangan label sangat diperlukan bagi panelis dalam menilai suatu produk dan 
untuk mendapatkan rasa percaya terhadap produk sesuai standar keamanan.

\section{Posisi Bersaing Keripik Singkong Cap Gerus}

Hasil penilaian 30 panelis atas kinerja 12 faktor keberhasilan penting pada keripik singkong cap Gerus produksi UKM Sumekar Pratiwi dan tiga pesaingnya dapat dilihat pada Tabel 5.

Berdasarkan pada Tabel 5, dapat diketahui kinerja keripik singkong cap Gerus menempati posisi kedua memiliki total skor $(3,116)$ lebih tinggi serta lebih unggul dibandingkan produk keripik singkong $C(2,058)$ dan keripik singkong $D(1,655)$, akan tetapi kalah dengan produk keripik singkong $B$ $(3,171)$. Hal tersebut dikarenakan produk keripik singkong B diproduksi oleh UKM yang selalu menjaga dan memperhatikan kualitas produk serta promosi yang dilakukan sangat efektif. Faktor lain yang menyebabkan produk keripik singkong $B$ diminati oleh konsumen adalah desain kemasan yang menarik yaitu tampilan pembuka kemasan dan kemudahan dalam membuka kemasan.

\section{Perumusan Alternatif Strategi Bersaing Keripik Singkong Cap Gerus}

Alternatif strategi bersaing yang dapat dirumuskan untuk produk keripik singkong cap Gerus adalah:

\section{Sales-force promotion}

Keunggulan produk yang terdapat pada keripik singkong cap Gerus yaitu rasa gurih yang pas, desain label yang up to date, informasi terhadap produk lengkap, dan merek yang sudah dikenal harus dipertahankan dan terus ditingkatkan untuk memperluas jaringan pasar. Strategi penguatan citra merek dagang dengan membuat tagline "kesehatan konsumen menjadi yang utama" diproduksi sesuai standar keamanan makanan sebagai langkah strategis untuk mempertahankan loyalitas konsumen berdasarkan pengalaman membeli dan membidik para konsumen baru melalui kegiatan sales-force promotion yaitu promosi yang bertujuan untuk memaksimalkan komponen pendukung penjualan agar permintaan produk meningkat. Tujuannya adalah jaringan pasar semakin luas, keripik singkong dengan branding cap Gerus semakin dikenal konsumen dan keuntungan yang diperoleh semakin meningkat.

\section{Positioning Sebagai Produk Berkualitas.}

Rasa gurih dan merek cap Gerus sudah banyak dikenal oleh masyarakat Kabupaten Tuban. Penggunaan nama merek cap Gerus terkesan unik dan simpel sehingga mudah diingat dan menambah citra positif dari keripik singkong. Desain label yang selalu diperbaharui (up to date) menjadi daya tarik bagi konsumen ditambah dengan pemilihan tulisan, pemilihan huruf, warna huruf, ukuran huruf sangat jelas dan tata letak desain sangat sesuai sehingga tampak menarik untuk dilihat. Label pada keripik singkong cap Gerus lebih lengkap dibandingkan pesaingnya. Pencantuman informasi pada label secara lengkap merupakan bentuk komunikasi kepada konsumen dan memberikan kemudahan konsumen dalam memilih produk yang aman dikonsumsi. Strategi positioning produk dapat dilakukan dengan memposisikan keripik singkong cap Gerus sebagai produk yang berkualitas dan aman dikonsumsi bagi semua kalangan, hal tersebut dapat dilakukan dengan membuat tagline "kualitas rasa gurih terpercaya 100\%" ditampilkan pada label kemasan dan "kesehatan konsumen menjadi yang utama". Penggunaan slogan tersebut menandakan bahwa keripik singkong cap Gerus selalu berusaha menghasilkan produk dengan kualitas terbaik dengan bahan-bahan yang berkualitas. Hal ini bertujuan untuk meningkatkan daya tarik terhadap produk sehingga keuntungan yang diperoleh semakin meningkat.

\section{Benchmark dengan produk pesaing.}

Benchmarking pada dasarnya belajar dari orang lain dengan menggunakan pengetahuan dan pengalaman orang lain untuk memperbaiki produk/organisasi. Hal ini dilakukan dengan menganalisis kinerja dan mencatat kekuatan dan kelemahan produk/organisasi serta menilai apa yang harus dilakukan untuk peningkatan sebuah produk/organisasi (Lankford, 2000). Warna produk keripik singkong cap Gerus berwarna cukup cerah keemasan dan cukup 
Agrisaintifika

Jurnal Ilmu-Ilmu Pertanian

Vol. 1, No. 1, 2017

Harisudin, et al. 2017

menarik (tidak gelap dan terlihat berwarna pucat) serta terdapat sedikit rasa pahit setelah mengonsumsi keripik singkong. Warna dan efek rasa akhir setelah makan keripik singkong cap Gerus kalah dengan produk pesaing, sehingga perlu untuk melakukan benchmark tampilan warna produk dan rasa yang tertinggalsetelah makan seperti keripik singkong B (cerah keemasan dan tidak pucat) untuk meningkatkan kepercayaan konsumen. Selain itu, untuk memperluas pasar dan menarik pelanggan dari pesaing dilakukan dengan cara menetapkan harga diskon kuantitas keripik singkong cap Gerus kepada konsumen akhir.

\section{SIMPULAN DAN SARAN Kesimpulan}

Berdasarkan pada hasil penelitian Strategi Bersaing Keripik Singkong Cap Gerus Produksi UKM Sumekar Pratiwi Kabupaten Tuban dapat ditarik kesimpulan sebagai berikut: Faktor-faktor penentu keberhasilan keripik singkong cap gerus adalah rasa, volume (gram), warna produk, kerenyahan, daya tahan, rasa akhir setelah makan, merek, harga, desain kemasan, kualitas kemasan, desain label, dan kelengkapan label; Hasil analisis CPM keripik singkong cap Gerus $(3,116)$ menempati posisi kedua dibandingkan dengan pesaingnya yaitu keripik singkong $C(2,058)$ dan keripik singkong D $(1,655)$, akan tetapi kalah dengan keripik singkong $B(3,171)$ yang berada pada posisi pertama; Alternatif strategi bersaing yang dapat dirumuskan untuk produk keripik singkong cap Gerus yaitu (1) Sales-force promotion, (2) Positioning sebagai produk berkualitas, (3) Benchmark dengan produk pesaing.

\section{Saran}

Berdasarkan analisis lapangan yang telah dilakukan di UKM Sumekar Pratiwi, maka saran yang dapat diberikan bagi UKM Sumekar
Pratiwi adalah selalu mempertimbangkan kualitas rasa, menjaga citra positif merek Gerus, selalu memperbarui dan meningkatkan desain label, serta menambah layanan informasi produk (website, facebook, instagram) pada label kemasan; mempromosikan brand cap Gerus secara efektif melalui kegiatan sales-force promotion dengan tagline "kesehatan konsumen menjadi yang utama" diproduksi sesuai standar keamanan makanan; melakukan positioning produk dengan menciptakan citra produk berkualitas dan aman dikonsumsi bagi semua kalangan, hal tersebut dapat dilakukan dengan membuat tagline "kualitas rasa gurih terpercaya $100 \%$ " ditampilkan pada label kemasan dan "kesehatan konsumen menjadi yang utama"; membuat akun media sosial (website, facebook, instagram) sebagai layanan informasi produk dan dicantumkan pada label kemasan guna menambah reseller atau agen dan konsumen, serta menyediakan layanan konsumen pada label kemasan terkait saluran komunikasi dalam bentuk nomor layanan telepon/alamat surat/alamat website; membentuk gugus kendali mutu (GKM) untuk memperbaiki warna produk yang cerah (tidak pucat), adanya efek rasa akhir yang pahit setelah makan; serta melakukan harga diskon kuantitas kepada konsumen akhir. Hal ini terkait dengan kelemahan daya saing harga dibandingkan dengan pesaing utamanya.

Rekomendasi kebijakan untuk Pemerintah Kabupaten Tuban: mengadakan pelatihan pada UKM produsen keripik singkong guna memperbaiki kualitas produk, aman, sehat, tahan lama, dan diterima pasar; mengadakan kegiatan pameran UKM secara efektif guna memperkenalkan UKM dan meningkatkan penjualan produk UKM.. 
Tabel 1. Daftar Merek Produk Keripik Singkong Produksi UKM yang Beredar di Kabupaten Tuban Tahun 2016

\begin{tabular}{lc}
\hline \hline \multicolumn{1}{c}{ Nama Industri } & Nama Merek Produk Keripik Singkong \\
\hline UKM Sumekar Pratiwi & Gerus \\
UKM Dian Pangestu & Bunga Tulip \\
UKM Yugus & YGS \\
UKM Al wira & Al wira \\
UKM Wahyu Barokah & Barbilla \\
UKM Dua Putra & Keripik \\
UKM Ana & Keripik Cap Ana \\
UKM Prima Rasa & Keripik Singkong \\
UKM Sarana Rezeki & Cap Bawang \\
\hline \hline
\end{tabular}

Sumber : Analisis Data Primer 2016

Tabel 2. Data Penjualan Keripik Singkong Produksi UKM Sumekar Pratiwi pada Bulan JanuariDesember Tahun 2016

\begin{tabular}{lccccc}
\hline \hline Bulan & $\begin{array}{c}\text { Keripik } \\
\text { Singkong } \\
\text { Original } \\
\text { 160 }\end{array}$ & $\begin{array}{c}\text { Keripik } \\
\text { Singkong } \\
\text { Original }\end{array}$ & $\begin{array}{c}\text { Keripik } \\
\text { Singkong } \\
\text { Original }\end{array}$ & $\begin{array}{c}\text { Keripik } \\
\text { Singkong } \\
\text { Balado }\end{array}$ & $\begin{array}{c}\text { Keripik } \\
\text { Singkong } \\
\text { Bamalado }\end{array}$ \\
& $\mathbf{2 5 0}$ & $\mathbf{5 0 0}$ & $\mathbf{1 6 0}$ & $\mathbf{5 0 0}$ \\
gram/pcs & gram/pcs & gram/pcs & gram/pcs \\
\hline Januari & 1.121 & 20 & 263 & 444 & 54 \\
Februari & 1.072 & 39 & 296 & 358 & 60 \\
Maret & 1.310 & 36 & 241 & 508 & 46 \\
April & 1.293 & 56 & 256 & 602 & 63 \\
Mei & 881 & 12 & 221 & 490 & 32 \\
Juni & 928 & 10 & 238 & 454 & 104 \\
Juli & 370 & 10 & 62 & 229 & 34 \\
Agustus & 958 & 13 & 166 & 429 & 47 \\
September & 877 & 137 & 179 & 398 & 39 \\
Oktober & 837 & 25 & 195 & 411 & 50 \\
November & 963 & 84 & 142 & 467 & 64 \\
Desember & 947 & 45 & 205 & 504 & 82 \\
\hline \hline
\end{tabular}

Sumber : Analisis Data Sekunder UKM Sumekar Pratiwi 2016 
Tabel 3. Penilaian bobot pada faktor-faktor penentu keberhasilan

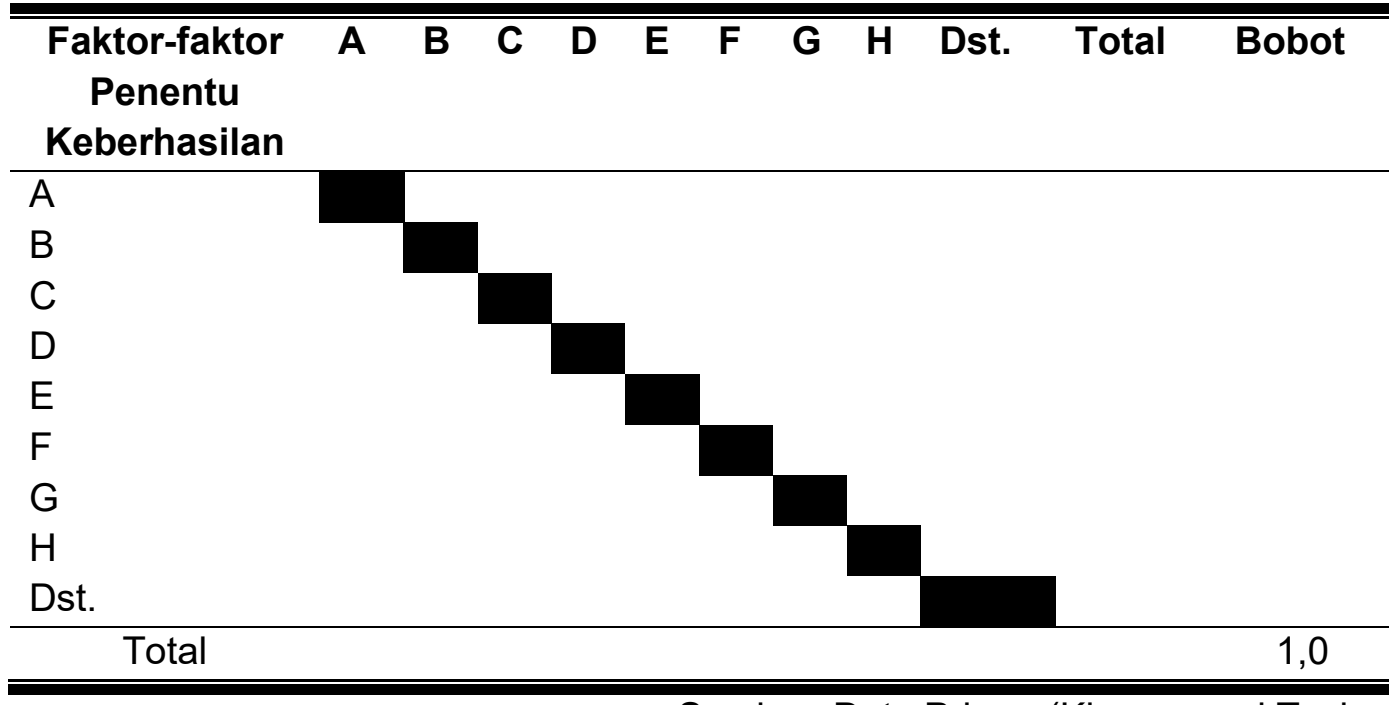

Sumber: Data Primer (Kinnear and Taylor, 1991).

Tabel 4. Analisis Competitive Profil Matrix (CPM)

\begin{tabular}{|c|c|c|c|c|c|}
\hline $\begin{array}{l}\text { Critical } \\
\text { succes } \\
\text { Factors }\end{array}$ & Bobot & $\begin{array}{c}\text { Keripik } \\
\text { Singkong } \\
\text { A } \\
\text { Rating } \\
\text { Skor }\end{array}$ & $\begin{array}{c}\text { Keripik } \\
\text { Singkong } \\
\text { B } \\
\text { Rating } \\
\text { Skor }\end{array}$ & $\begin{array}{c}\text { Keripik } \\
\text { Singkong } \\
\text { C } \\
\text { Rating } \\
\text { Skor }\end{array}$ & $\begin{array}{c}\text { Keripik } \\
\text { Singkong } \\
\text { D } \\
\text { Rating } \\
\text { Skor }\end{array}$ \\
\hline $\begin{array}{l}1 . \\
2 . \\
3 . \\
4 . \\
\text { Dst. }\end{array}$ & & & & & \\
\hline Total & 1,00 & & & & \\
\hline
\end{tabular}


Tabel 5. Matriks Profil Kompetitif Persaingan Keripik Singkong

\begin{tabular}{|c|c|c|c|c|c|c|c|c|c|c|}
\hline \multirow[t]{2}{*}{ No } & \multirow[t]{2}{*}{$\begin{array}{l}\text { Critical succes } \\
\text { Factors }\end{array}$} & \multirow[t]{2}{*}{ Bobot } & \multicolumn{2}{|c|}{$\begin{array}{l}\text { Keripik } \\
\text { Singkong } \\
\text { Gerus }\end{array}$} & \multicolumn{2}{|c|}{$\begin{array}{c}\text { Keripik } \\
\text { Singkong B }\end{array}$} & \multicolumn{2}{|c|}{$\begin{array}{c}\text { Keripik } \\
\text { Singkong C }\end{array}$} & \multicolumn{2}{|c|}{$\begin{array}{c}\text { Keripik } \\
\text { Singkong D } \\
\end{array}$} \\
\hline & & & Rating & Skor & Rating & Skor & Rating & Skor & Rating & Skor \\
\hline 1 & Rasa & 0,097 & 4 & 0,388 & 3 & 0,291 & 1 & 0,097 & 2 & 0,194 \\
\hline 2 & Volume (gram) & 0,073 & 3 & 0,219 & 2 & 0,146 & 4 & 0,292 & 1 & 0,073 \\
\hline 3 & Warna produk & 0,080 & 2 & 0,16 & 4 & 0,32 & 1 & 0,080 & 3 & 0,24 \\
\hline 4 & Kerenyahan & 0,078 & 3 & 0,234 & 4 & 0,312 & 1 & 0,078 & 2 & 0,156 \\
\hline 5 & $\begin{array}{l}\text { Daya tahan } \\
\text { Rasa akhir }\end{array}$ & 0,083 & 3 & 0,249 & 4 & 0,332 & 1 & 0,083 & 2 & 0,166 \\
\hline 6 & setelah makan & 0,076 & 2 & 0,152 & 4 & 0,304 & 3 & 0,228 & 1 & 0,076 \\
\hline 7 & Merek & 0,088 & 4 & 0,352 & 3 & 0,264 & 2 & 0,176 & 1 & 0,088 \\
\hline 8 & Harga & 0,087 & 2 & 0,174 & 3 & 0,261 & 4 & 0,348 & 1 & 0,087 \\
\hline 9 & $\begin{array}{l}\text { Desain } \\
\text { kemasan } \\
\text { Kualitas }\end{array}$ & 0,085 & 3 & 0,255 & 4 & 0,34 & 2 & 0,17 & 1 & 0,085 \\
\hline 10 & kemasan & 0,079 & 3 & 0,237 & 1 & 0,079 & 2 & 0,158 & 4 & 0,316 \\
\hline 11 & $\begin{array}{l}\text { Desain label } \\
\text { Kelengkapan }\end{array}$ & 0,088 & 4 & 0,352 & 3 & 0,264 & 2 & 0,176 & 1 & 0,088 \\
\hline 12 & label & 0,086 & 4 & 0,344 & 3 & 0,258 & 2 & 0,172 & 1 & 0,086 \\
\hline & Total & 1 & & 3,116 & & 3,171 & & 2,058 & & 1,655 \\
\hline
\end{tabular}

Sumber : Analisis Data Primer

\section{DAFTAR PUSTAKA}

Capps, CJ, Glissmeyer, MD. 2012. Extending The Competitive Profile Matrix Using Internal Factor Evaluation And External Factor Evaluation Matrix Consept. The Journal of Applied Business Research. 28(5): 1059-1062

David, FR. 2011. Strategic Management Concepts and Cases, Thirteenth Edition. Prentice Hall. Boston

Fahy, J 2002. A Resource-Based Analysis of Sustainable Competitive Advantage in a Global Environment. International Business Review.11(1): 57-77.
Harisudin, M. 2011. Competitive Profile Matrix Sebagai Alat Analisis Strategi Pemasaran Produk atau Jasa. Jurnal Sepa. 7(2): 80-84

Jaya, MM, Nurcholis, M. Estiasih, T. Saparianti, E. and Zubaidah, E.2011. Keripik Umbi Inferior: Aneka Bentuk dan Rasa. Pengabdian Masyarakat di Bandulan Malang. Malang, 30 Oktober. 2011.

Kinnear, TC and Taylor, JR. 1991. Marketing Research, An Applied Approach. New York: Mc.Graw Hill.

Lankford, WM. 2000. Benchmarking: Understanding the Basic. Journal The Coastal Business. 1(1):57-62 
Agrisaintifika

Jurnal Ilmu-Ilmu Pertanian

Vol. 1, No. 1, 2017

Harisudin, et al. 2017

Matthews, JH. and Shulman, AD. 2005 Competitive advantage in Public sector organizations: Explaining the public good/sustainable competitive advantage paradox, Journal of Business Research. 58(2): 232-240.

Nawawi, H. 2003. Metode Penelitian Bidang Sosial. Yogyakarta: Gadjah Mada University Press.

Porter, ME 1998. Strategi Bersaing (terjemahan Sigit Suryanto). Jakarta: Karisma Publishing Group.

Rangkuti, F. 1997. Riset Pemasaran. Jakarta: PT. Gramedia Pustaka Utama.
Rukmana, HR. 2011. Aneka Keripik Umbi. Yogyakarta. Kanisius.

Soekarto, ST. 1981. Penilaian Organoleptik untuk Industri Pangan dan Hasil Pertanian. Bogor. IPB Press

Sutopo, HB. 2002. Metodologi Penelitian Kualitatif. Surakarta. UNS Press.

Vorhies, DW and Morgan, NA 2005. Benchmarking Marketing Capabilities for Sustainable Competitive Advantage. Journal of Marketing.69 (1): 80-94. 